\title{
Global Cholas: Reworking Tradition and Modernity in Bolivian Lucha Libre
}

\author{
By \\ Nell Haynes \\ Pontifica Universidad Católica de Chile
}

\begin{abstract}
Resumen
Este artículo examina las mujeres luchadoras en La Paz, Bolivia, y cómo usan creativamente los supuestos por parte de los turistas de ser "tradicionales" y de que están actuando en eventos "exóticos." Desde 2001, mujeres indígenas participan en la lucha libre - una forma de lucha procedente de México y los Estados Unidos. Sin embargo, los viajeros, a menudo, asumen que es una tradición porque las luchadoras se presentan con los trajes de las cholas vendedoras. En este artículo exploro cómo las luchadoras utilizan esas percepciones y la atención resultante de los medios de comunicació n para reclamar identidades cosmopolitas. Con ello no solo mejoran su posición y ganan movilidad social, sino tambiíen se ven a sí mismas cómo representantes de las mujeres bolivianas ante un público global. [Bolivia, género, globalización, indígenas, turismo]
\end{abstract}

\begin{abstract}
This article examines indigenous women wrestlers (luchadoras) in La Paz, Bolivia, and the ways in which they creatively use tourists' assumptions that they are "traditional" peoples performing in "exotic" events. Since 2001, indigenous women have participated in lucha libre-a form of wrestling that draws its lineage from wrestling in Mexico and the United States. Travelers often assume it represents a traditional form, however, because the luchadoras base their wrestling personas and costuming on chola market women. I explore how the luchadoras utilize these perceptions and the resulting media attention to claim cosmopolitan identities. Not only do they gain social status and mobility, but they also see themselves as positive representatives of Bolivian women for a global audience. [Bolivia, gender, globalization, indigenous peoples, tourism]
\end{abstract}

In central La Paz, Bolivia, just behind the San Francisco church is a little lunch restaurant called Almuerzo Carmen Rosa: hidden away in a courtyard, it does not look like anything special. In fact, I walked past it three times before finding it, wondering if the directions I had been given were inaccurate. When I finally walked in, I found the internationally famous proprietor, Carmen Rosa. Although the lunch sated my appetite, I had not really come for the food, and the food was not the reason Carmen Rosa had achieved international fame. Carmen Rosa is well known in Bolivia, South America, and across the world as la campeo'n of women's wrestling.

Carmen Rosa is one of the cholitas luchadoras-Bolivian women who wrestle each other and men in weekly events more aptly described as "sports entertainment" than athletic competition. Bolivian lucha libre draws its lineage from Mexican lucha libre, and more distantly from professional wrestling in the United States. Much like these other forms of wrestling, Bolivian luchadores utilize fictional storylines, humor, and performative violence in social commentary. The luchadoras, dressed in sparkly skirts and shawls, often wrestle against male luchadores, who wear clothing ranging from skintight hot pink spandex to mummy or werewolf costumes. In these choreographed matches, they jump from the ropes, flip their bodies, and body slam each other, while trying to win the match by pinning their opponent for a count of three.

These events are popular among both locals and international tourists, drawing about 500 spectators each Sunday evening. They have also attracted a remarkable amount of international media attention. When I asked Carmen Rosa about this she replied, "For me its very interesting the people from other countries come to see me. And they record me and put it on the internet, on Youtube, so many more people are going to know who Carmen Rosa is and are going to see how Bolivian women are."

Carmen Rosa's comments point to some of the ways tradition and modernity have been fused in cholitas luchadoras' performances. The luchadoras draw on the Andean icon of the chola, which has historically been endowed with a number of racialized and gendered meanings (Albro 2000; Weismantel 2001), although tourists who view the performances usually assume that the chola is simply a traditional Bolivian woman. In fact, lucha libre is far from being a "traditional" Bolivian pastime, but the Andean Secrets tour company and Titanes del Ring wrestling organization play on tourists' understanding of cholas as traditional in order to attract audiences. Much anthropological work has problematized notions of tradition and modernity, pointing out that they are interpreted differently by different individuals (Besnier 2004:9; Knauft 2002b; Pavis 1996:9), but the concepts also operate as powerful anchor points for negotiating identities, actions, and institutions (Knauft 2002a:131-134). As I will show, the cholitas luchadoras have successfully invoked a representation of traditional Bolivian 
femininity in order to position themselves as cosmopolitan actors on a global scale. As Carmen Rosa indicates in the statement above, in her opinion, this has also allowed her and other luchadoras to become visible examples of Bolivian women for cosmopolitan audiences both in person and through forms of media.

In three periods of fieldwork carried out between July 2009 and November 2012, I interviewed several luchadoras, as well as Bolivian lucha libre business owners, wrestling trainers, male luchadores, local audience members, and international travelers who viewed Titanes del Ring events. Before seeing the events, most tourists assumed they would be attending a form of wrestling event that was local to Bolivia. The tourists' comments sparked my interest in relation to the ways that foreign travelers understood the characters and action of the wrestling events. As an important consumer base for both the Andean Secrets tour company and the Titanes del Ring wrestling organization, their attendance and interpretations are an integral aspect of the overall phenomenon of lucha libre in Bolivia.

The following article explores how tourists' desires to view traditional performances are mediated and used by the luchadoras to gain social capital and visibility as positive examples of Bolivian women on a global scale. The opportunities created by international sensationalism around cholitas luchadoras have given these working-class women a new and fairly lucrative employment option. Understanding the shows as mutually constructed by performers and audience clarifies the ways in which travelers' expectations influence representations, while the luchadoras use these representations to "show the world" what Bolivian women are like. By using their own form of strategic essentialism, the luchadoras are able to both gain recognition and claim their own versions of cosmopolitan modernity.

\section{Lonely Planeteers, Andean Secrets, and Titanes del Ring}

During my first week of fieldwork in July 2009, I joined young travelers on the Andean Secrets tour bus from a local backpackers' hostel to the multipurpose arena in El Alto. As I rode the bus for 40 minutes from the center of La Paz, I heard many conversations about what my fellow passengers anticipated from the cholitas luchadoras. On this Sunday and several others, I overheard a number of discussions about whether this was a traditional event in Bolivia. Most travelers assumed that the wrestling must be rooted in "community practices" or "indigenous customs" rather than acknowledging the ways that Bolivian lucha libre is part of the globalized phenomenon of exhibition wrestling.

Most of the travelers who attend Titanes del Ring events are similar to the "lonely planeteers" described by Notar (2008). They are backpackers or independent vacationers traveling for as brief a time as a few months or as long as several years. Most come from North America, Europe, urban South Africa, Australia, and New Zealand. In La Paz, most hostel patrons are young, middle-class people who travel through several different countries, if not continents. Most have limited budgets, and spend about $\$ 10$ per night to share a dormitory- like room in a hostel with nine other travelers, rather than renting a private room at a La Paz hotel, which can range in price from $\$ 20$ to $\$ 200$ per night. Although these travelers usually do not have the extensive economic resources or elite class status often associated with cosmopolitanism, their mode of orientation to the world (Hannerz 1990) makes them emblematic cosmopolitan figures; they are mobile individuals who enjoy encounters with difference, but are always "just passing through" (Molz 2006:5). Their destinations may simply be "home plus," as Hannerz terms it: "Spain is home plus sunshine, India is home plus servants, Africa is home plus elephants and lions" (1990:241). La Paz may well be home plus mountains and cholitas.

Andean Secrets very much capitalizes on the desire for "home plus," transporting tourists directly from their hostels to the arena and providing them with the best seats, snacks, and souvenirs in a package deal. The tour company is owned by Daniela, a Paceña (from La Paz) woman in her mid-thirties and she employs about ten guides. The company offers tours to some outdoor scenic attractions, but their profits primarily come from lucha libre tourism. Travelers pay about \$12USD and Daniela estimates they have about 150-200 clients per week. Their advertising is generally directed toward the "lonely planeteer" types of travelers, so it is not unusual to see their posters behind hostel reception desks, and the company's employees handing out flyers to hostel guests on Sunday mornings.

The Lonely Planet (2007) guidebook, which many travelers carry with them, cautions that El Alto is full of pickpockets and warns readers to keep an eye on their cameras and other personal belongings. Indeed, in the busy market outside of the arena it would be wise to follow such advice. El Alto is more than just a "dangerous" market, however. It is an undoubtedly working-class and indigenous city, with 74 percent of residents identifying as a member of an indigenous group (Lazar 2008). It is a city that has long been a first stop for migrants from rural areas moving to the city. Many of these families migrated in the 1980s and 1990s seeking employment as a result of the World Bank-generated New Economic Policy, which privatized industries such as mining and downsized government jobs, leaving thousands of workers unemployed. For many of the unemployed, moving to La Paz from rural areas and smaller cities was the best option. El Alto was an important point of migration even before it was officially incorporated as a city in 1988. For tourists, the presence of rural migrants lends it an air of authenticity. Given that most of the women they view through the bus windows appear to be of indigenous origin and dress in a traditional fashion, the differences between El Alto and the city center of La Paz set the stage for performances that highlight "tradition."

Thus, those audience members who enter the arena expecting a traditional performance are interpreting the cues around them. However, after the first match they understand that the events are much like professional wrestling from the United States, which they have probably seen on television. Bolivians were introduced to lucha libre in the 1960s, when Mexican wrestlers such as Huracaán Ramirez, Rayo de Jalisco, and Lizmark traveled through much of Latin America, forming lucha 
libre organizations in many countries, including Bolivia. Because Mexican lucha libre itself was an offshoot of exhibition wrestling in the United States, lucha libre throughout Latin America reflects the rules, characters, and other conventions of more globalized wrestling entertainment, such as World Wrestling Entertainment (WWE, formerly WWF).

Titanes del Ring is one of four major lucha libre companies in La Paz, and by far attracts the most foreign audience members. When attending events put on by Luchadores Independientes De Enorme Riesgo (Independent Wrestlers of Enormous Risk, LIDER), Super Catch, or Lucha Fuerza Extrema (Extreme Force Wrestling), I felt like the only foreigner in the crowd. By contrast, at Titanes del Ring events, the 500-member audience consists of about 40 percent foreign travelers. The other 60 percent of the audience is composed of local El Alto citizens, who attend with their families and friends. As both Daniela and Carlos (the Titanes del Ring publicity representative) attest, the high number of foreigners attending these events is a direct result of trips organized by Andean Secrets.

Titanes del Ring is comprised primarily of male wrestlers with names such as Angel Azul (Blue Angel) and Hombre Lobo (Wolfman) who wear tight-fitting spandex unitards and full head masks. Before 2001, women would occasionally wrestle wearing similar spandex outfits. In 2001, some luchadoras began dressing in costumes that mimic the clothing of chola market women, and their popularity rocketed. Most luchadoras now dress in a style referred to as de pollera, after the large layered pollera skirts worn by rural Bolivians and market women.

Today, luchadoras wrestle both each other and male luchadores, performing not as themselves but as characters they or their promoters invent. Like the men's characters, cholitas luchadoras are often morally coded as good and bad (técnicos and rudos), with each match featuring the meeting of two moralized sides. Rudos use unnecessary roughness, trickery, and display cowardice, while técnicos are generally more graceful and acrobatic. The luchadoras use stage names and have concocted personalities that reflect the extreme morality of good and evil; for example, Juanita la Cariñosa (Juanita the Caring One), is a técnica and Jennifer Dos Caras (Two-Faced Jennifer), is a ruda.

In January 2012, I began training with the wrestlers of Super Catch, a small lucha libre group in La Paz. In doing so, I learned far more about wrestlers' lives outside of the ring than I had through interviews. Most of the approximately 30 luchadoras in the La Paz area are relatively young, ranging from their late teens to early thirties. Based on the estimations of several luchadoras, about 80 percent are the daughters or sisters of male luchadores. None support their families entirely with earnings from lucha libre. Like the restaurateur, Carmen Rosa, they have jobs as nurses, secretaries, and one is part of the cleaning crew of several embassies. Many are mothers who stay at home with young children while their husbands work, and some have children old enough that they have begun wrestling as well. They usually live in working-class neighborhoods like San Pedro in Central La Paz, Villa Victoria, higher up on the mountain in La Paz, or near La Ceja market area in El Alto. Although they arrive at television interviews or photo shoots wearing the same beautiful polleras they don in the ring, when training they wear tracksuits and t-shirts. Most dress 'de vestido' (in Western-style clothing) when not acting as their luchadora character. Super Catch luchadoras Betty and Mercedes always arrived at the arena wearing tight jeans and high-heeled boots. In the locker room before and after matches, Betty used her Android phone to exchange text messages with her friends or take pictures of herself with several of the male luchadores hanging around backstage.

\section{Representing the Chola}

Although one could (and many do) spend much time debating whether lucha libre is "real" or "fake," the extent to which the productions engage an audience with flashy costumes, charismatic characters, and compelling storylines is undeniable. Exhibition wrestling events often have choreographed moves. There are referees but they usually function as symbols of sport rather than actually enforcing rules, and sometimes they even help the rudo character. Indeed, matches almost invariably involve some form of cheating or rule breaking. Many locals and travelers find the wrestling events to be compelling because the characters and storylines are farcical and full of humor. They provide commentary on social or political events, such as national alliances or tensions, problematic social situations-gang violence, undocumented immigration, military brutality - or notions of difference rooted in gender, race, or nationality.

Given the social commentary embedded in the wrestling events, local working-class spectators who make up the majority of the audience are the primary focus and understand the chola characters more thoroughly than tourist audiences. Middle-class and elite Paceños know of the events because of media attention, but few actually attend the events, and thus the luchadoras do not address them or craft their performances with elites in mind. Instead, the performances are fashioned for the dual audiences of working-class Alteños (El Alto residents) and young tourists.

The chola, as a symbol of tradition, is found in a number of venues in La Paz. Folkloric dance festivals often feature young women in cholita costumes composed of brightly colored tiny bowler hats, revealing blouses, short, sparkly layered skirts, and stacked heel boots. Young mestiza women promoting dessert brands in upscale supermarkets wear a more conservative but refined version of chola clothing, perhaps capitalizing on the association of cholas with agriculture and nourishment. The quintessential rural chola appears on thousands of postcards throughout the region, as if her picture was captured in a place and time untouched by modernity.

As these various incarnations make clear, the widely circulating image of the chola has been divorced from real chola market women (Albro 2000:69). Indeed, Canessa observes that as a result of nationalizing projects of the 1950s, "indigenous culture [has been] glorified, but as folklore rather than contemporary culture" (2006:245). Specifically, representations of 
indigeneity aimed at tourists tend to be focused on appearing colorful and exotic, rather than reflecting the real lives of indigenous-identified people (Canessa 2006:244). Thus, indigeneity becomes associated with a certain notion of tradition that envisions indians as a locus of culture that has persisted since colonial times or before. Women, more so than men, tend to be identified as the bearers of this tradition.

Marisol de la Cadena first pointed out in her work on indigeneity and mestizaje in the Andes of Peru that women are perceived as "more indian" than men. While modernization has opened options for cultural mestizaje to most men, it has reinforced the indianization of women (de la Cadena 1995:343). Several scholars have built upon her argument, providing examples of how indigenous women's seeming connection to indigeneity has been used advantageously. Albro (2000) demonstrates the ways in which politicians in Quillacollo, Bolivia, present themselves as close to cholas in order to demonstrate they are close to community roots, while Annelou Ypeij (2010) explains how women who vend to tourists in the Peruvian Andes are able to negotiate financial and community power despite being more bound to the community than most men. In fact, it is the perception by tourists of these women as community-bound and traditional that makes them financially successful. As Little (2004) confirms, women in traditional dress are often the preferred vendors of tourist goods because they are seen as repositories of cultural tradition. Thus, while de la Cadena connects women's subordinate status to the fact that they seem to be ma's indígena, many women have been able to turn their status as more indian into a financial asset.

The cholitas luchadoras capitalize on the fact that "the indian" has become a commodity, and is recognized throughout the world as a symbol of traditional lifestyles (Canessa 2005:4). Although both men and women may acquire "modern" skills and be perceived as less indian and more mestizo, for women, the advantage to be gained is more modest because of the intersections of their status and the structures of both community and household (Babb 2011:153). Instead, highlighting their Otherness for foreigners is more advantageous for women in tourist industries. Doing just that allows the luchadoras to capitalize on travelers' desires and preconceptions.

In English-language advertisements (that are presumably aimed at foreigners) the events are referred to as "The Fighting Cholitas." There are no photographs or mention of the male luchadores. In the ring, it is only the women who dress in a traditional way, with bowler hats, fringed shawls, elaborate jewelry, and polleras reminiscent of chola market women. Although much of this is removed before the wrestling match begins, the pollera remains, creating fantastic swirls of color through the air as the luchadoras jump from the top ropes or flip their opponents.

\section{Performances and Possibilities}

Images of women de pollera have roots in the folkloric expression of indigenous peoples of the hacienda era, when ethnic hierarchy was institutionalized (Albro 2000:66). But today, many Alteños, some of whom wear polleras themselves, say that the image of a mujer de pollera in the ring has come to symbolize the strength and empowerment of Bolivian women. In colonial and hacienda era ideology, a mujer de pollera was by definition indigenous. Colonizers justified indigenous peoples' exploitation under the belief that they represented a stagnated state of development and were less civilized, prone to violence, and dangerous when left to their own devices (Wade 1997:27). These thoughts appeared to be confirmed by periodic indigenous revolts against oppressive governments from the time of colonization to the present day (Hylton and Thomson 2007:19). The pollera, then, is synonymous with the woman who wears it-capable of revolt and, unlike elite women who were more confined to the domestic sphere, assertive and aggressive in public. The bulky pollera may seem strange attire for wrestling, especially compared to men's tight-fitting costumes, but as the ultimate visual index of the chola, it actually makes sense in the wrestling ring. Weismantel writes that the pollera, as worn in everyday life, announces the rejection of certain aspects of femininity, in which dress and body language express an implicit promise to be nice, agreeable, and passive: "The wearer of the pollera . . promises to put up a good fight" (2001:130). Although the luchadoras perform a specific kind of femininity, they are far from passive, flipping opponents and kicking them while they are on the ground.

As one young Bolivian man explained to me while we were watching a match, cholitas luchadoras are popular with local audiences because "since the colonial era Bolivian women have been fighters." Diana, a young female fan, explained further:

\footnotetext{
To me it is a great example of courage and strength. In all of Bolivia, the cholitas show not only strength, but also hard work and dedication ... Who says women can't fight in the ring? It is a historical milestone not only because there are wrestlers like Jennifer Dos Caras (who wrestles de vestido, that is, in Western dress), among others, but because there are cholitas ... I think the fact that they have gone into the ring in polleras and mankanchas has sparked the euphoria of the people. ${ }^{2}$
}

This feeling was summarized more simply by another female audience member, who told me, "I like to see the woman winning because it demonstrates her strength."

The luchadoras know that among local women attending these events, polleras are as common as blue jeans. They create a sense of identification and empathy with audience members and hope their characters are iconic not just of the chola but of the women of El Alto: indigenous and mestiza, hard working, subject to structural violence and forms of oppression, but nonetheless potentially powerful. As luchadora Juanita la Cariñosa explained to me, "We are proud to be luchadoras, not 
only for the show, but also to get into people's heads." ${ }^{4}$ As audience responses confirm, many spectators do feel the empathy luchadoras hope to evoke.

Luchadoras also use the pollera to create an appeal to authenticity as well as empathy. As Daniela suggested, the pollera is "something very authentic ... it has a very Bolivian characteristic." ${ }^{5}$ Foreign audience members confirmed Daniela's assumptions, saying that they wished to attend because they wanted to see "Bolivian culture." As Jane Desmond asserts, "many, many people are willing to pay a lot of money to see bodies which are different from their own, to purchase the right to look, and to believe that through that visual consumption they have come to know something that they didn't before" (1999:xiii). The polleras mark the luchadoras as "different," and thus are important for generating income for Andean Secrets and Titanes del Ring.

The luchadoras consciously play up their difference for tourist audiences, but audience members play an equal role in the meanings of performance. Meanings emerge not simply from the action, but as products of an interactive process in which the audience is an active participant (Goodwin 1986:284). Audience members make sense of the performance by linking it to a broader context (Duranti 1986:243-244). Although Dell Hymes (1981:82) would suggest that only members of a community with access to folk knowledge could truly understand performances, even travelers with little background knowledge are part of the interactive process. Performance, like other aesthetic modes, is a key site in which difference is transformed into discourse, allowing the audience to make meaning (Marcus and Meyers 1995:34). Thus, understanding cholas as symbols of tradition and the Bolivian nation becomes central to travelers' interpretations of lucha libre.

In 2009, I asked William, a British student in his early twenties, if he knew what a chola was. He responded, "I think it just [means] Bolivian woman, but I'm not sure." Then his friends Ben and Jack chimed in, reminding him that cholas were always traditional women. Their assertion reflects hundreds of travel blogs that describe cholitas luchadoras as "women in traditional dress." Other travelers associate the word with the market women (vendedoras) they see on the streets and in markets. While on the tourist bus in 2011 , a mujer de pollera walked by the window carrying her wares wrapped in a manta shawl on her back. The Welsh woman behind me exclaimed, "Oh, that's what a 'chola' is, right?"

Others have slightly more insight into what cholas represent in the local context. Anne, a young woman from the United States, suggested that they might be associated with Bolivian feminism. When she and I discussed a feminist organization in La Paz, she asked, “Are they the ones that wear the big skirts? Because they're Bolivian? Because they're feminist?" In her statements, the idea of the mujer de pollera as an archetype of Bolivian femininity remained ingrained. When she complimented the beauty of some polleras, she suggested that I should buy one and wear it for Halloween: "You could get [a pollera] and one of those little bowler hats and a shawl and go as a Bolivian!" For her, like many other travelers, indigenous identity remains more symbolic commodity than lived experience.

For many tourists, the luchadoras are perceived as both signs and signifiers of them- selves. This "staged authenticity" (MacCannell 1989) is a mode of performance in which representations become understood as more real than the living beings that are performing. The cholitas luchadoras represent both the average indigenous woman as well as the ideal- ized icon of the chola, and thus contribute to the widely circulating icon of the chola that has been divorced from the reality of indigenous market women.

Much literature on tourism focuses on the notion of authenticity, or a sense of naturalness in the local community, and the desire of tourists to see "life as it is really lived" (MacCannell 1989:94). MacCannell (1989:101), drawing on Goffman (1959), explains that authenticity is partially dependent on an illusion of the entry into "backstage" areas, when the entry is actually only into a front stage set up for tourists. Cholita wrestling does not maintain its sense of being backstage for long. It is obviously a scripted spectacle and, furthermore, it clearly resembles the exhibition wrestling of the United States that most travelers have often seen on television. Some experience disappointment when they realize lucha libre is much like professional wrestling in other countries, rather than a traditional Bolivian pastime.

This disappointment confirms that the neo-colonial imaginary of the timeless Third World is still strongly held, despite the reality of globalization processes. The globalized nature of lucha libre becomes all too apparent within the actual shows. A few days after the performance Ben told me, "It was so amateur. I just can't see any tradition in it whatsoever . . . that was far too WWF. You know what I mean? Americanized. There's no way that can be tradition." Further, when asked why these women might want to wrestle, Jack suggested the wrestling must be part of some sort of ritual. Although anthropologists understand ritual as a broad category of performativity into which many daily acts might fall (Turner 1987), when I asked Jack what he meant by ritual, his stumbling response used the words "tradition," "custom," and "community."

Later in the conversation, William demonstrated this view again when he contemplated why women might wrestle:

I can [understand] women wrestlers fighting in like, a circle over some sort of argument . . . an issue in the community - to be resolved-between the community. And they do it via wrestling. Via a fight basically, but I couldn't think of any reason you'd do it in [lucha libre] style.

The idea of this wrestling being connected to global media or serving a function other than community cohesion seemed implausible to some foreign audience members. 
Indeed, many audience members participate in the creation of what Alneng calls "touristic phantasms": "imaginaries" of incidents and people about whom they posses no memories but around whom they structure "fantasies and actions" (Alneng 2002:465-466). These phantasms no doubt motivate many travelers to attend Titanes del Ring events, although the wrestling does not live up to these imaginaries. Many tourists are disappointed, and the incongruity between their desire for tradition and the globalized nature of wrestling may provide a site for shifting understandings of tradition and modernity.

Recent anthropological work (Bruner 2001; Charsley 2004; Peterson 2011) has examined how disadvantaged groups have navigated competing interpretations of tradition and modernity to carve out social and economic niches for themselves. Although traditional and modern economic and social processes may support markedly different value systems, they often work jointly to maintain inequalities (Rofel 2002:177; Schein 1999:267-272). However, disadvantaged groups and individuals often creatively rework cultural and per- formative resources, variously considered modern or traditional, in order to assert new subjectivities (Knauft 2002a:105-107).

Many anthropologists take a critical stance toward representations of tradition for tourists, seeing these formations as "exchanging ritual for money" (Bharucha 1984:17). They suggest the danger emerges when spectacle "replaces narrative, and with it the possibility of historical reflection" (Desmond 1999:xvi). Although they note that reductive representations of indigeneity often feed into foreigners' concepts of exotic or primitive Others (Fusco 1994:143), the juxtaposition of tradition within a performance genre considered to be thoroughly modern may help to shift audience understandings of tradition.

The cholitas luchadoras' use of the traditional chola icon may be understood as a form of "disidentification." Muñoz describes disidentifications as "survival strategies" that minority subjects practice to avoid the social elision or punishment resulting from nonconformance to normative citizenship (1999:4). He suggests that these survival strategies involve processes and performances in which the subject neither identifies (as a good citizen-subject) nor counter-identifies (by resisting or rejecting) with particular ideological structures (Pêcheux 1982:156-157). Disidentification is "a working of the subject-form and not just its abolition" (1982:158). Thus, performance becomes a space where actors may manipulate symbolic meanings and, through the acts of representation, may problematize fixed identity (Deloria 1998:7).

Cholitas luchadoras utilize multiple subject positions in a process of reworking their own identities. In performances, they present themselves as regional icons for local audiences and as symbols of traditional Bolivian culture for tourist audiences. In doing so they increase their ticket sales. Mun oz suggests that in an era marked by the dominance of liberal capitalism, subjectivities are formed in response to the cultural logics that support state power (1999:5). Indeed, the luchadoras, most of whom are working class, have been especially vulnerable to the neo-liberal economic policies imposed upon Bolivians over the last two decades, which have disproportionately affected rural areas, lower classes, and people of indigenous origins (Kohl 2002:449). The subjectivities of the luchadoras, as well as their cholita characters, are formed not only in relation to state power, but to international processes and institutions that occupy global positions of power as well.

The ability to appeal to foreigners is especially important for profits, given that tourists pay more than five times the price of a local ticket (about \$12 vs. \$2) and constitute a significant portion of the audience. Veteran LIDER wrestler and trainer Ben Simonini highlighted for me the economic importance of foreigners to the wrestling business in Bolivia:

Its good to have tourists . . Because they come with money, it's not a pain . . Here in La Paz, for example, in this kind of economy .... in the end the guy is digging [for money]. My coworkers are also digging. It's not a profession, to do this. It could be much better. But, for example the cholitas attract foreigners ... What more can I say? ${ }^{6}$

Indeed, attracting foreigners is truly an economic survival strategy for the luchadoras and their associates. By presenting a particularly traditional vision of Bolivian femininity, they combat the economic inequalities with which they live, and which have resulted from thoroughly modern economic policies: by doing so, they take on a disidentificatory subject position.

However, most luchadoras told me they did not begin wrestling for the money. Their pay per event ranges between 4 and 20 USD - enough to supplement family income, but not nearly enough to support them entirely. Instead, what they highlight in interviews is the social status and mobility they have achieved as a result of their participation in wrestling events. Bourdieu uses the term "social capital" to refer to a "usable set of resources and powers," which can garner an individual or a group a level of influence, privilege, and authority within a web of social relationships (Bourdieu 1984:114). As the Super Catch luchadora Antonia walked me around her El Alto neighborhood one day before an interview, she stopped in several shops to say hello to her neighbors: "If you want to come to my house and you forget where it is, just ask anyone: Where is Antonia the luchadora's house?"7 Being well known in her community was not only something Antonia enjoyed, but something she wanted to demonstrate, as she took me to meet her friends working in a photograph developing shop, an arcade, a party favor store, and several cake shops along Avenida 16 de Julio.

Luchadoras also point to wider networks of social capital as important. Across Europe, North America, and South America, the luchadoras have been subjects of photo spreads (Abbate 2008; Cobelo 2011; Crooker 2010; Guillermoprieto 2008), news stories (Carroll and Schipani 2008), television spots (The Christina Show; The Great Race), and documentary films (Mamachas del Ring 2009; The Fighting Cholitas 2007). Carmen Rosa, a veteran luchadora, told me that starring in the documentary Mamachas del Ring (2009) was the greatest moment of her wrestling career. She elaborated upon this, saying that she was always excited to show the documentary to her neighbors, family, and friends. Similarly, when interviewing luchadoras who had been featured in magazines, they often brought copies of their articles to show me. These ranged from 
international publications like National Geographic, to local weekly papers such as Alarma, which regularly features a short biography on a luchador or luchadora.

The luchadoras are similarly eager to tell me about their travel opportunities that have arisen because of lucha libre. Most luchadoras who have been wrestling for a few years have traveled throughout Bolivia, South America, and occasionally to other continents for performances. The most popular places for travel are Santa Cruz in Southeastern Bolivia, Chile, Brazil, and Peru, but some of the most talented are asked to travel outside of South America. When I first met Juanita, she immediately showed me her passport, and pointed out her US visa. Even a tourist visa for the US is notoriously hard to achieve for Bolivians, and she very much appreciated that her involvement in lucha libre had given her an opportunity so many people would never get. Juanita had appeared on the Cristina Show, a daytime Spanish language talk show broadcast on the Univisión cable channel from Miami, Florida. She beamed with pride telling me about her first international television appearance and meeting Cristina. She also told stories about traveling to Tokyo, where she performed with female Japanese wrestlers. Similarly, Carmen Rosa talked at length after our first interview about traveling to New York for the premiere of Mamachas del Ring. After asking me how I liked Bolivia, she recounted how much she had loved being in the United States and feeling like a celebrity for a few days. Wrestling, for women like Carmen Rosa and Juanita, allows new exposure and travel opportunities, granting them a mobility that is rare among Bolivian women of their economic background.

Lucha libre has given women who wrestle access to forms of cosmopolitanism unimaginable to working-class and indigenous women a decade ago. For the luchadoras, their motivation for wrestling comes from a sense of cosmopolitanism that is broader than access to wealth and privilege, but still relies heavily on a mobility associated with transnational movement. In essence, they have complicated cosmopolitan travelers' assumptions about tradition, while claiming their own sense of cosmopolitanism.

Indeed, some luchadoras see their performances as in direct contrast with "old- fashioned" lifestyles. Juanita explained that she views her work as helping rural Bolivians to "modernize":

There is still illiteracy in rural areas, and there are people who don't know how to dress well or how to interact with people still ... There are people that live in old-fashioned and conservative ways, so there are still women who suffer from physical and psychological abuse and violence. They are afraid. And they haven't studied so they don't know much about our world these days or how our reality has changed . . . But I think that's going to change, it's going to change soon. We are actually an example of that change. We are role models. ${ }^{8}$

Particularly in declaring that cholitas luchadoras are role models, Juanita suggests that the changes are not just important for the wrestlers themselves, but that they are leaders for a much broader group of indigenous and rural people in Bolivia. For Juanita, the luchadoras represent a form of modernity to which rural people should aspire. She mentions illiteracy, lack of schooling, and abuse of women as indications of 'old fashioned and conservative' lives. She later spoke about women in a way that sheds light on the characteristics she sees as positive and modern: "Women are fighters now. They work in offices, for example, they have jobs as architects, lawyers, and more. The only thing that makes us different from women in other countries is how we dress. We are intelligent. We are beautiful."

Carmen Rosa also speaks to modernity and cosmopolitanism, describing how she believes the luchadoras have demonstrated the characteristics of Bolivian women to the world:

I think that people have realized that thanks to us, the cholitas luchadoras, the world knows what Bolivian women are really like. Here, women are not only abused, humiliated, manip- ulated by men, we have shown that Bolivian women, Aymara women are also strong, have heart, have courage. ${ }^{10}$

Here, Carmen Rosa positions cholitas luchadoras not only as Bolivia's "contribution to the world of wrestling" but as ambassadors to the world at large. Cholitas luchadoras, as icons of "the Bolivian woman," demonstrate their strength to people who assume that women from an underdeveloped country would be weak, afraid, and subject to machista violence. Thus, she claims two forms of modernity at once: global visibility and gender equality.

\section{Conclusion}

As luchadoras' increased social capital makes clear, locals must be understood as something more than passive recipients of "touristic invaders." Edward Bruner (2005:17-18) instead stresses that locals and travelers are engaged in a "coproduction." The luchadoras with their juxtaposition of traditional and modern make evident the flexibility of these concepts as ideological regimes. Through negotiated performances, marginal actors claim agency by "establishing new possibilities" for the ways in which notions of tradition and modernity are received, interpreted, and reproduced (Mun oz 1999:30). Luchadoras draw on nostalgic notions of traditional indigenous women, through dress and naming, but as William as- tutely points out, "there's no way you can say this [wrestling] is traditional." In exposing the impossibility of static notions of tradition, the luchadoras reform understandings of difference within particular global relations of power.

Perhaps more importantly, however, these women use lucha libre as a means of claiming new forms of social capital, and particularly a sense of cosmopolitanism. By performing representations of a traditional icon, the luchadoras are able to claim 
a form of cosmopolitan modernity, articulating a locally relevant form of social change (Knauft 2002b:14). David Aruquipa Pe 'rez-a prominent LGBT activist in La Paz-suggests, "Their marginality has transgressively positioned their public presence to appropriate a national and international popularity." ${ }^{11}$ Indeed, it is the international popularity itself that has, to an extent, become the "transgression."

As Dwight Conquergood asserts, "It is no longer easy to sort out the local from the global: transnational circulations of images get reworked on the ground and redeployed for local, tactical struggles" (2002:145). The relationships between cholitas luchadoras of $\mathrm{La} \mathrm{Paz}$ and foreign travelers who attend their shows provide a striking example of the ways in which tradition and modernity have become intertwined. Rather than presenting audiences with the traditional performance they expect, luchadoras complicate notions of tradition and modernity in multiple ways. For the travelers, they throw into question whether untouched tradition may exist in a world characterized by crosscutting flows of popular culture and accumulation of cultural resources. At the same time, they use their own representation of certain character aspects deemed traditional to claim thoroughly modern, cosmopolitan subjectivities, even considering themselves role models for other Bolivians and ambassadors to the world.

\section{Notes}

${ }^{1}$ Desde la época de la colonia la mujer Boliviana ha sido guerrera.

${ }^{2}$ Me parece que [la lucha libre de cholitas] es una gran muestra de valor y de fuerza. La cholita en toda Bolivia no solo muestra trabajo y fuerza sino también esmero ... Quien dijo que las mujeres no podían pelear en un ring? Es un hito histórico no solo porque ya desde antes habían luchadoras en el ring como Jennifer Dos caras entre otras pero es que las cholitas ... Creo que el hecho de haber subido polleras y mankanchas a un ring ha desatado la euforia de la gente. Me gusta ver a la mujer ganando, porque demuestra su fuerza.

${ }^{3}$ Nos sentimos orgullosas de ser luchadoras no solo por el espectáculo sino también por entrar a la psicología de la gente.

${ }^{4}$ Algo muy autentico ... tiene una caracterista muy Boliviana.

${ }^{5}$ Bien tener turistas ... porque vienen con plata no es la pena ... Aca en La Paz por ejemplo, en esa manera de economía ... A los finales el señor esta hurgando. Están hurgando mis compañeros de trabajo también. No es una profesión a hacerlo. Pero por ejemplo las cholitas atraen extranjeros ... Que más puedo decir?

${ }^{6}$ Si quieres venir a mi casa y te olvidas donde esta, simplemente pregunta a cualquier persona: ¿Dónde está la casa de Antonia la luchadora? Si quieres venir a mi casa y te olvidas donde está, simplemente pregunta a cualquier persona: ¿Dónde está la casa de Antonia la luchadora?

${ }^{7}$ Aún hay analfabetismo en lugares rurales, y gente que no sabe como vestir bien o interactuar con otra gente todavía ... Hay gente que viven en maneras viejas y conservativas así que aun hay mujeres que sufren abuso y violencia física y psicología. Tienen miedo. Y no han estudiado así que no saben mucho en nuestro mundo hoy en día, o como cambió nuestra realidad ... Pero creo que va a cambiar, va a cambiar pronto. Justamente somos un ejemplo de ese cambio. Somos modelos a seguir.

${ }^{8}$ Mujeres son luchadoras ahora. Trabajan en officinas, por ejemplo, tienen trabajos como architectas, abogadas, y más. The unica cosa que nos hace diferente que mujeres en otros paises es como vestimos. Somos intelligentes. Somos bellas.

${ }^{9}$ Creo que la gente ha realizado que, gracias a nosotras las cholitas luchadoras, el mundo sabe como son mujeres Bolivianas en realidad. Aqui, las mujeres no solo estan abusadas, humilladas, manipulados por hombres. Hemos demonstrado que mujeres Bolivianas, mujeres Aymaras tambien son fuerte, tienen corazón, tienen el coraje.

${ }^{10}$ La marginalidad han posisionado transgresoramente su presencia pùblica hasta apropiarse de una popularidad nacional e internacional.

\section{References Cited}

Abbate, Florencia. (2008) Entre Faldas y Costalazos. D' 1a Siete 429. 9 November. Pp 38-42. www.diasiete.com/xml/pdf/ 429/15CHOLAS.pdf. Accessed 10 July 2009.

Albro, Robert. (2000) The Populist Chola: Cultural Mediation and the Political Imagination in Quillacollo, Bolivia. Journal of Latin American Anthropology 5(2):30-88.

Alneng, Victor. (2002) The Modern Does Not Cater for Natives: Travel Ethnography and the Conventions of Form. Tourist Studies 2:119-142.

Babb, Florence. (2011) The Tourism Encounter: Fashioning Latin American Nations and Histories. Stanford, CA: Stanford University Press.

Besnier, Niko. (2004) Consumption and Cosmopolitanism: Practicing Modernity at the Second-hand Marketplace in Nuku'alofa, Tonga. Anthropological Quarterly 77(1):7-45.

Bharucha, Rustom. (1984) A Reply to Richard Schechner. Asian Theatre Journal 1(2):254-260.

Bourdieu, Pierre. (1984) Distinction: A Social Critique of the Judgement of Taste. Translated by Richard Nice. Cambridge: Harvard University Press.

Bruner, Edward M. (2005) Culture on Tour: Ethnographies of Travel. Chicago, IL: University of Chicago Press.

- - - (2001) The Maasai and the Lion King: Authenticity, Nationalism, and Globalization in African Tourism. American Ethnologist 28(4):881-908.

Canessa, Andrew. (2006) Todos somos ind igenas: Towards a New Language of National Political Identity. Bulletin of Latin American Research 25(2):241263.

- - - (2005) Natives Making Nation: Gender, Indigeneity, and the State in the Andes. Tucson, AZ: University of Arizona Press.

Carroll, Rory and Andre's, Schipani. (2008) Bolivia: Welcome to Lucha Libre - The Sport for Men Making Heroes of Women. The Guardian. August 30. http://www.guardian.co.uk/world/2008/aug /30/bolivia.gender. 30. Accessed 28 October 2008.

Charsley, Simon. (2004) Interpreting Untouchability: The Performance of Caste in Andhra Pradesh, South India. Asian Folklore Studies 63(2):267-290.

Cobelo, Lu' 1s. (2011) Bolivia-Peru' 2011. Yo Estuve Ah'1. 16 June. http://luiscobelo.blogspot.com/2011/06/bolivia-peru-2011.html. Accessed 3 July 2011.

Conquergood, Dwight. (2002) Performance Studies: Interventions and Radical Research. Drama Review 46(2):145-156. 
Crooker, Patricio. (2010) Luchadores. Aymara Lucha Libre. American Ethnography Quasimonthly. http://www.americanethnography.com/gallery.php?id=94. Accessed 4 October 2011.

de la Cadena, Marisol. (1995) Women are More "Indian": Ethnicity and Gender in a Community near Cuzco. In Ethnicity, Markets, and Migration in the Andes. Brooke Larson and Olivia Harris, eds. Pp. 329-348. Durham: Duke University Press.

Deloria, Philip J. (1998) Playing Indian. New Haven, CT: Yale University Press.

Desmond, Jane C. (1999) Staging Tourism: Bodies on Display from Waikiki to Sea World. Chicago, IL: University of Chicago Press.

Dösserich, Beatriz Andrade. (2009) Vitrina Nacional: Brillo y Color en la Mujer de Pollera. Mia (Magazine of La Razon newspaper, La Paz Bolivia) August 7:12-14.

Duranti, Alessandro. (1986) The Audience as Co-author: An Introduction. Text 6(3):239-347.

The Fighting Cholitas. (2007) Mariam Jobrani, dir. 20 min. At Risk Films, West Hollywood, CA.

Fusco, Coco. (1994) The Other History of Intercultural Performance. Drama Review 38(1):143-167.

Goffman, Erving. (1959) The Presentation of Self in Everyday Life. Garden City, NY: Prentice Hall.

Goodwin, Charles. (1986) Audience Diversity, Participation, and Interpretation. Text 6(3):283-316.

Guillermoprieto, Alma. (2008) Cholitas Fight Back. National Geographic, 112-125.

Hannerz, Ulf. (1990) Cosmopolitans and Locals in World Culture. In Global Culture: Nationalism, Globalization and Modernity. Mike Featherstone, ed. Pp. 237-252. London: Sage.

Hylton, Forrest, and Sinclair Thomson. (2007) Revolutionary Horizons: Past and Present in Bolivian Politics. New York, NY: Verso.

Hymes, Dell. (1981) In Vain I Tried to Tell You. Philadelphia, PA: University of Pennsylvania Press.

Knauft, Bruce. ed. (2002a) Trials of the Oxymodern: Public Practice at Nomad Station. In Critically Modern: Alternatives, Alterities, Anthropologies. Pp. 10143. Bloomington, IN: Indiana University Press.

- - (2002b) Critically Modern: An Introduction. In Critically Modern: Alternatives, Alterities, Anthropologies. Pp. 1-54. Bloomington, IN: Indiana University Press.

Kohl, Benjamin H. (2002) Stabilizing Neoliberalism in Bolivia: Popular Participation and Privatization. Political Geography 21:449-472.

Lazar, Sian El Alto. (2008) Rebel City: Self and Citizenship in Andean Bolivia. Raleigh, NC: Duke University Press.

Little, Walter E. (2004) Mayas in the Marketplace: Tourism, Globalization, and Cultural Identity. Austin, TX: University of Texas Press.

Lonely Planet Bolivia (2007) Bolivia. $6^{\text {th }}$ edition. Oakland, CA: Lonely Planet Publications.

Mamachas del Ring. (2009) Betty M. Park, dir. 75 min. My Tragic Uncle Productions, Brooklyn, NY.

Marcus, George, and Fred Meyers. (1995) The Traffic in Culture: Refiguring Art and Anthropology. Berkeley, CA: University of California Press.

MacCannell, Dean. (1989) The Tourist: A New Theory of the Leisure Class. New York, NY: Schocken Books

Molz, Jennie Germann. (2006) Cosmopolitan Bodies: Fit to Travel and Traveling to Fit. Body Society 12:1-21.

Muñoz, Jose' Esteban. (1999) Disidentifications: Queers of Color and the Performance of Politics. Minneapolis, MN: University of Minnesota Press.

Notar, Beth E. (2008) Producing Cosmopolitanism at the Borderlands: Lonely Planeteers and "Local" Cosmopolitans in Southwest China. Anthropological Quarterly 81(3):615-650.

Pavis, Patrice, ed. (1996) Introduction: Towards a Theory of Interculturalism in Theatre? In The Intercultural Performance Reader. Pp. 1-26. London: Routledge.

Pêcheux, Michel. (1982) Language, Semantics, and Ideology. New York, NY: St Martin's Press.

Peterson, William. (2011) Amazing Show in Manila: "Fantasy Production" and Filipino Labor in a Transnational, Transcultural, Transgendered Theatre Enterprise. Theatre Journal 63(1):587-605.

Rofel, Lisa. (2002) Modernity's Masculine Fantasies. In Critically Modern: Alternatives, Alterities, Anthropologies. Bruce Knauft ed. Pp. 175-193. Bloomington, IN: Indiana University Press.

Schein, Lisa. (1999) Performing Modernity. Cultural Anthropology 14(3): 361-395.

Turner, Victor. (1987) Carnival, Ritual, and Play in Rio de Janeiro. In Time Out of Time: Essays on the Festival. A. Falassi, ed. Pp. 74-92. Albuquerque, NM: University of New Mexico Press.

United Nations World Tourism Organization. (2011) Compendium of Tourism Statistics. Madrid, Spain: World Tourism Organization.

Wade, Peter. (1997) Race and Ethnicity in Latin America. London: Pluto Press.

Weismantel, Mary. (2001) Cholas and Pishtacos. Chicago, IL: University of Chicago Press.

Ypeij, Annelou. (2010) Tourism, and the Ambiguous Revaluation of Women's "Indianness": Stories of Indigenous Women Successfully Working in the CuscoMachu Picchu Region. Paper presented at 109th Annual meeting of the American Anthropology Association. New Orleans, LA. 